\title{
Speciation and potential long-term behaviour of chromium in urban sediment particulates
}

\author{
Patrick Byrne $^{1}$ - Kevin G. Taylor ${ }^{2} \cdot$ Karen A. Hudson-Edwards $^{3} \cdot$ Judith E. S. Barrett $^{4}$
}

Received: 31 May 2016 / Accepted: 8 September 2016 /Published online: 26 September 2016

(C) The Author(s) 2016. This article is published with open access at Springerlink.com

\begin{abstract}
Purpose Chromium, a potentially harmful element, occurs commonly within the urban sediment cascade as a result of abundant industrial and transport-related sources. The risks that Cr-bearing particles pose to ecosystems and humans depend on the solid-phase chemical speciation of $\mathrm{Cr}$ and its environmental mobility. In this study, we adopt an integrated geochemical approach to investigate and determine the longterm fate of $\mathrm{Cr}$ in the urban sediment cascade.

Materials and methods We use bulk chemical digests, sequential chemical extraction analysis, electron microscopy, electron microprobe and microfocus XANES analysis to describe the solid-phase speciation, geochemical characteristics and potential long-term behaviour of $\mathrm{Cr}$ in urban particulate matter from both aquatic sediment and road dust sediment (RDS) in Manchester, UK.

Results and discussion Cr-bearing grains within RDS and aquatic sediment are predominantly iron oxides and alumino-silicate glass grains. Electron microprobe analysis indicates $\mathrm{Cr}$ concentrations up to 3300 and $133,400 \mu \mathrm{g} \mathrm{g}^{-1}$
\end{abstract}

Responsible editor: Marcel van der Perk

Patrick Byrne

p.a.byrne@ljmu.ac.uk

1 School of Natural Sciences and Psychology, Liverpool John Moores University, L3 3AF, Liverpool, UK

2 School of Earth and Environmental Sciences, The University of Manchester, Manchester M13 9PL, UK

3 Department of Earth and Planetary Sciences, Birkbeck, University of London, WC1E 7HX, London, UK

4 Centre for Earth and Ecosystem Responses to Environmental Change, School of Science and Environment, Manchester Metropolitan University, Manchester M1 5GD, UK in the RDS and aquatic grains, respectively. XANES analysis indicates that $\mathrm{Cr}$ (III) is the dominant oxidation state, with only trace amounts of $\mathrm{Cr}(\mathrm{VI})$. Importantly, $\mathrm{Cr}$ speciation does not appear to have changed between sedimentary environments and the dominance of $\mathrm{Cr}$ (III) suggests limited bioavailability or toxicity under predominant environmental (anoxic and neutral $\mathrm{pH}$ ) conditions in the aquatic sediment sink. Furthermore, geochemical analyses suggest the environmental mobility of $\mathrm{Cr}$ in the aquatic sediment sink is low (compared to other toxic metals) due to its association mainly with alumino-silicate glass grains and its inclusion as an integral part of the glass structure.

Conclusions Industrial glass grains are a major component of urban sediment worldwide. The speciation and geochemical investigations performed in this study suggest most $\mathrm{Cr}$ within the urban sediment cascade may be resistant to environmental processes that could mobilise other toxic metals.

Keywords Chromium $\cdot \mathrm{Cr}(\mathrm{III}) \cdot \mathrm{Cr}(\mathrm{VI}) \cdot$ Glass grain $\cdot$ Urban sediment $\cdot$ XANES

\section{Introduction}

Chromium $(\mathrm{Cr})$ has long been known to be a potentially harmful element within the environment (Nriagu and Nieboer 1988). Humans and ecosystems can be exposed to Cr through natural and anthropogenic pathways in water and particulate (soil, sediment and aerosol) matter (Werner et al. 2007). However, the risks that Cr-bearing particles pose to ecosystems and humans depend on the solid-phase chemical speciation and environmental mobility of $\mathrm{Cr}$ in the particles (Kotas and Stasicka 2000). In the environment, Cr exists primarily in two oxidation states-trivalent chromium [Cr(III)] and hexavalent chromium $[\mathrm{Cr}(\mathrm{VI})]$. Under anoxic conditions, 
cationic $\mathrm{Cr}$ (III) is typically the dominant form and is relatively stable and non-toxic at circum-neutral $\mathrm{pH}(6.5-8.5)$ due to the formation of insoluble hydroxide and oxide compounds and strong complexation with minerals and organic matter (Martello et al. 2007). Chromium(III) is an essential element for organisms and, in small quantities, is required for sugar and lipid metabolism (Anderson 1989; Broadway et al. 2010). Under oxic conditions, anionic $\mathrm{Cr}(\mathrm{VI})$ tends to dominate; it is soluble and can be mobile across the full $\mathrm{pH}$ range. There is clear evidence of the toxicological risk and carcinogenic properties of $\mathrm{Cr}(\mathrm{VI})$ in humans and aquatic ecosystems (Broadway et al. 2010; Stern 2010; Ohgami et al. 2015). As such, Cr is widely recognized as a potentially harmful element and listed as a contaminant of serious concern in environmental legislation worldwide.

Chromium occurs within urban environments around the globe as a result of abundant industrial and transport-related sources (Owens et al. 1999). Important sources are vehicle tyres and brake linings, steel production, combined sewer overflows (CSOs), municipal discharges and industrial effluents including chromite ore processing residue (COPR) and tannery effluent. Chromium contamination of urban freshwater sediments, road dust sediment and air-borne particulate matter has been widely reported (Valerio et al. 1988; Yu et al. 2008) and speciation studies have generally observed Cr(III) to dominate (Martello et al. 2007; Werner et al. 2007; Broadway et al. 2010; Swietlik et al. 2011; Landrot et al. 2012). This information has proved useful for assessing the potential toxicity of $\mathrm{Cr}$ in urban particulate matter assuming stable environmental conditions. However, environmental change driven by the dynamic urban environment and/or climatic forces has the potential to affect the long-term environmental mobility and toxicity of $\mathrm{Cr}$ in these sediments (Calmano et al. 1993; Butler 2009; Knott et al. 2009). In order to understand the potential long-term behaviour of $\mathrm{Cr}$ in complex substances such as urban particulate matter, a synergistic and grain-specific approach is required that incorporates bulk and grain-specific chemical analysis and spectroscopic techniques such as scanning electron microscopy (SEM), x-ray powder diffraction (XRD) and synchrotron-based x-ray absorption spectroscopy (XAS) techniques such as X-ray absorption near edge structure (XANES) (Xia et al. 1997; Manceau et al. 2002; Berry and O’Neill 2004; Wei et al. 2007; Barrett et al. 2010, 2011; Chen et al. 2010). The major advantage of grain-specific analyses over bulk sediment analyses is that the major host species for contaminants can be identified and subjected to geochemical analyses to determine environmental mobility. A case in point are the metal-rich glass grains that are major constituents of both terrestrial (Lottermoser 2002) and freshwater (Taylor and Boult 2007) urban particulates as a consequence of furnace-derived slag from steel production. These are known to contain high concentrations of trace elements $(\mathrm{Pb}, \mathrm{Cu}, \mathrm{Cr}, \mathrm{Zn}, \mathrm{Ni})$ and have been identified in urban particulate matter worldwide (Kida and Sakai 2001; Lind et al. 2001; Reich 2003; Saffarzadeh et al. 2009; Taylor and Robertson 2009). Following deposition in urban water bodies, the ultimate sink for contaminated urban particulates, these glass grains have been observed to undergo dissolution and early diagenetic reactions potentially releasing $\mathrm{Cr}$ to interstitial and overlying waters (Taylor and Boult 2007).

In this paper, we adopt an integrated speciation and geochemical approach to describe the solid-phase speciation and environmental mobility of $\mathrm{Cr}$ in urban particulate matter from the Greater Manchester urban conurbation, UK. To the authors' knowledge, this is the first time such an integrated approach has been adopted to study toxic element cycling through urban sediment systems. The specific objectives of this study were to: (1) investigate the association of $\mathrm{Cr}$ with terrestrial and aquatic urban particulates; (2) confirm the speciation of $\mathrm{Cr}$ in these particulates and (3) investigate the potential long-term geochemical mobility of $\mathrm{Cr}$ associated with urban particulates. This innovative approach could provide a strong evidence base for assessing the long-term risk of $\mathrm{Cr}$ to human health and ecosystems in urban environments.

\section{Materials and methods}

\subsection{Study area and sampling procedures}

The contaminated sediment described in this study is from the urban conurbation of Manchester, UK. The road dust sediment (RDS) samples were obtained from locations within Manchester city centre that comprised heavily urbanised environments with high traffic densities (Fig. 1a). Samples were collected by sweeping with a polyethylene dustpan and brush. High metal ( $\mathrm{Fe}, \mathrm{Mn}, \mathrm{Pb}, \mathrm{Zn}, \mathrm{Cu}$ ) concentrations have been reported in these sediments and sequential extraction analysis has shown some metals (Fe, Mn, Zn) are largely associated with the reducible fraction, suggesting changes in ambient $\mathrm{pH}$ and/or Eh could mobilise these metals (Robertson et al. 2003). Trace metals $(\mathrm{Pb}, \mathrm{Cu}, \mathrm{Zn}, \mathrm{Cr}, \mathrm{Ni})$ in the RDS material are hosted mainly in iron oxides and iron-rich glass grains (Taylor and Robertson 2009). Speciation studies using X-ray absorption spectroscopy (XAS) have identified both $\mathrm{Pb}$ (Barrett et al. 2010) and Zn (Barrett et al. 2011) to exist in phases that are potentially harmful to human health. The aquatic sediment was sampled from the Salford Quays (Fig. 1b), a historically contaminated urban water body that received domestic and industrial sewage and road runoff prior to commencement of remediation activities in the late $1980 \mathrm{~s}$. Urban water bodies represent major sinks for contaminated sediment in urban centres worldwide (Taylor and Owens 2009). Sediment cores were retrieved from basin 9 of the Salford Quays in 2000 and 2001 using a stainless steel corer and contain a mix of natural and anthropogenic detrital grains, 
Fig. 1 Location of Manchester showing a RDS sampling sites in Manchester city centre and $\mathbf{b}$ aquatic sediment sampling site in the Salford Quays

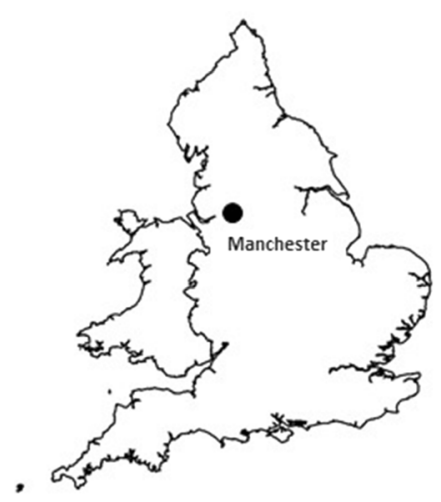

(a)

(b)

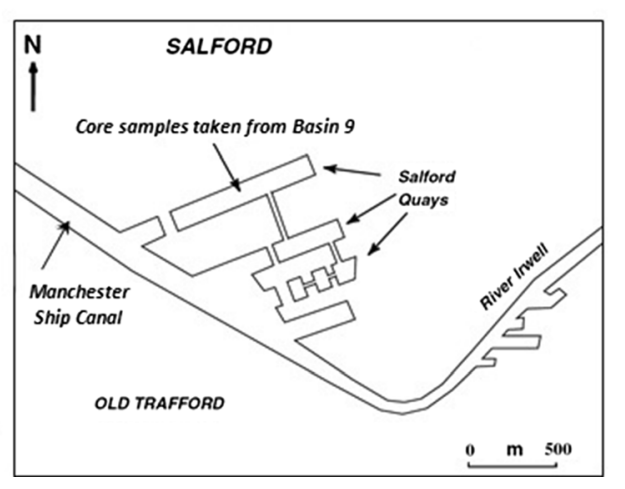

the latter dominated by alumino-silicate glass grains (Taylor and Boult 2007). Petrographic analysis indicated these glass grains were undergoing chemical dissolution supplying $\mathrm{Fe}$ and $\mathrm{Zn}$ to porewaters while bacterial $\mathrm{Fe}(\mathrm{III})$ and $\mathrm{Mn}(\mathrm{IV})$ reduction was hypothesised to supply $\mathrm{Fe}^{2+}$ and $\mathrm{Mn}^{2+}$ to porewaters. Whilst these previous studies (and others) have greatly increased our understanding of trace metal geochemistry in urban environments, they have tended to focus on elements (e.g. $\mathrm{Fe}, \mathrm{Mn}, \mathrm{Zn}, \mathrm{Pb}, \mathrm{Cu}$ ) that represent, by mass, the bulk of metal contaminants found in urban environments. Here, we focus specifically on the trace metal $\mathrm{Cr}$, an element which may display different geochemical and mobility characteristics to those more typically studied metals.

\subsection{Elemental analysis of RDS and aquatic sediment}

Petrographic and quantitative chemical data were obtained through the use of scanning electron microscopy and electron microprobe analysis. Air-dried samples of RDS and aquatic sediment were impregnated with epoxy resin and polished surface blocks were produced. The petrography of the samples was analysed with JEOL (Tokyo, Japan) 5600LV (for RDS) and JEOL JXA 8100 (for aquatic sediment) electron microprobes using backscattered electron imagery. Wavelength dispersive spectrometers (WDS) were used to obtain quantitative data on major and trace element composition of mineral grains. Analysis of $\mathrm{SiO}_{2}, \mathrm{Al}_{2} \mathrm{O}_{3}, \mathrm{TiO}_{2}, \mathrm{CaO}, \mathrm{Na}_{2} \mathrm{O}, \mathrm{K}_{2} \mathrm{O}$, $\mathrm{Fe}_{2} \mathrm{O}_{3}, \mathrm{MnO}, \mathrm{MgO}, \mathrm{P}_{2} \mathrm{O}_{5}, \mathrm{SO}_{3}$ (all in wt\%), and $\mathrm{Cr}$ (in ppm) were undertaken in WDS mode using an accelerating voltage of $15 \mathrm{kV}$, current of $2.5 \mathrm{nA}$, electron beam diameter of $1 \mu \mathrm{m}$ and counting time of $10 \mathrm{~s}$. The analyses were calibrated against standards of natural silicates, oxides and Specpure ${ }^{\circledR}$ (Waltham, MA, USA) metals with the data corrected using a ZAF program.

\subsection{Molecular-scale analysis of RDS and aquatic sediment}

XANES is sensitive to the oxidation state, continuation and bonding environment around a central atom of transition elements such as $\mathrm{Cr}$, both in single and mixed complexes, for example, amorphous material, silicate glasses and particulate matter (Pantelouris et al. 2004; Farges 2009). XANES data were collected at station I18 at the Diamond Light Source, UK, in September 2010. XAS spectra were collected at the Cr K-edge $(5989 \mathrm{eV})$. Operating conditions for the storage ring were $3 \mathrm{GeV}$ and $200 \mathrm{~mA}$. On I18, which is an undulator beamline, the $\mathrm{x}$-rays are focused by a pair of Kirkpatrick-Baez (KB) mirrors after being monochromated by a Si (111) double-crystal monochromator. Experiments were performed at ambient temperature. Standard spectra were collected for model compounds $\left[\mathrm{Cr}(\mathrm{OH})_{3}, \mathrm{Cr}\right.$ foil, $\left.\mathrm{Cr}(\mathrm{III}), \mathrm{Cr}(\mathrm{VI})\right]$ and these were analysed in transmission mode. The urban 
particulate samples were presented to the beam in resinimpregnated polished blocks. In these, the distribution of $\mathrm{Cr}$ in individual grains was mapped using $\mu \mathrm{XRF}$ and $\mathrm{Cr}$ XAS data were collected in fluorescence mode for qualitatively high-Cr areas ( $\mu$ XRF did not quantify the $\mathrm{Cr}$ concentrations). Data processing was carried out using ATHENA (to convert from monochromator position in millidegrees to energy in $\mathrm{eV}$ and to average multiple spectra from individual standards and samples; Ravel and Newville (2005)) and PySpline (to carry out background subtraction and normalization; Tenderholt et al. (2007)). The fluorescence signal is calculated as the total windowed fluorescence counts divided by $I_{\mathrm{o}}$. The normalization was done by fitting a first-order polynomial to the preedge region and extrapolating this to the end of the spectrum, then subtracting. A second-order polynomial was fitted to the post-edge region and subtracted. The edge step was normalized to 1 . No linear combination modelling was undertaken due to the uncertainties around the appropriate model compounds.

\subsection{Geochemical analysis of alumino-silicate glass grains}

Alumino-silicate glass grains were identified as a major constituent of terrestrial and aquatic sediments and were, therefore, subjected to further geochemical analysis to determine the environmental mobility of associated $\mathrm{Cr}$. Glass grains were hand-picked from the aquatic sediment under a binocular microscope. Samples of sediment were washed in distilled water and the $<63-\mu \mathrm{m}$ fraction was sieved away leaving behind silt- and sand-sized fractions. The glass grains were generally coarse sand in size and were also dark and shiny, allowing easy separation. Pseudo-total $\mathrm{Cr}$ concentrations of the glass grains were determined by aqua-regia digestion in closed vessels using a CEM MARS Xpress microwave apparatus (Matthews, NC, USA). A three-step sequential extraction procedure (SEP) recommended by the Standards, Measurements and Testing programme (SM\&T) of the European Union (Rauret et al. 1999) was utilised to extract bioavailable $\mathrm{Cr}$ from the glass grains. The chemical procedure extracts metals bound to three specific geochemical phases: (1) acid-soluble, easily exchangeable, and bound to carbonates; (2) reducible, bound to iron, and manganese oxides and (3) oxidisable, bound to organic, and sulphide compounds. The SM\&T procedure is the only SEP with a certified reference material (CRM 701) (Quevauviller et al. 1997) for all three phases of extraction allowing validation of the procedure and comparison of results between studies. The SEP included two sample duplicates, one blank and the certified reference material. The $\mathrm{Cr}$ content in the residual fraction of the glass grains was estimated as the difference between pseudo-total content (microwave extraction) and the sum of the contents of the other fractions obtained by SEP. The supernatants produced after both extraction procedures were acidified to $\mathrm{pH}$
2 and stored at $4{ }^{\circ} \mathrm{C}$ prior to analysis. All solutions were analysed within a month using inductively coupled plasma (ICP) optical emission spectroscopy (OES) (PerkinElmer Optima 2100DV) (Waltham, MA, USA). Detection limits of the ICP-OES were $0.05 \mathrm{ppm} \mathrm{Cr}$. High precision $( \pm 10 \%)$ of the control standards is reported and calibration curves had a coefficient value better than 0.99 . The relative standard deviation was less than $2 \%$ above $0.05 \mathrm{ppm} \mathrm{Cr}$. Recovery rates for $\mathrm{Cr}$ in the CRM 701 were $95 \%$ for step 1, $91 \%$ for step 2, and $101 \%$ for step 3.

\section{Results}

\subsection{Elemental analysis of RDS and aquatic sediment}

Cr-bearing grains within RDS and aquatic sediments are characterized primarily by iron oxides and alumino-silicate glass grains derived from industrial waste. Aquatic sediment is dominated by glass grains comprising Fe-rich and Fe-poor varieties with inclusions of metal-rich blebs and dark crystalline areas. Electron microprobe analysis indicates the Fe-rich glasses have high concentrations of $\mathrm{Cr}$ (mean $347 \mu \mathrm{g} \mathrm{g}^{-1}$ ), $\mathrm{Fe}$ (mean $38.5 \% \mathrm{FeO}$ ) and $\mathrm{Al}$ (mean $7.93 \% \mathrm{Al}_{2} \mathrm{O}_{3}$ ) (Table 1). The Fe-poor glasses contain lower concentrations of $\mathrm{Fe}$ (mean $9.15 \% \mathrm{FeO}$ ), $\mathrm{Cr}$ (mean $226 \mu \mathrm{g} \mathrm{g}^{-1}$ ) and other metals (Table 1). Dark glass inclusions in the Fe-rich glasses contain Cr-rich areas up to $133,360{\mu g^{-1}}^{-1}$ mean 69,800 $\mathrm{gg} \mathrm{g}^{-1}$ ). Crbearing grains within the RDS are predominantly iron oxide grains but Cr-bearing silicate glass grains are also present. Electron microprobe analysis indicates concentrations of $\mathrm{Cr}$ up to $3300 \mu \mathrm{g} \mathrm{g}^{-1}$ (mean $425 \mu \mathrm{g} \mathrm{g}^{-1}$ ) in these grains (Table 1). Examples of $\mathrm{Cr}$-bearing grains in the RDS samples are shown in Fig. 2. WDS analysis of these grains shows them to be $\mathrm{Fe}$ oxides ((a), (b), (e) and (f)), a mixed Fe-Al-silicate and Fe-Mgsilicate (c) and a Fe silicate (d) (Table 1). All grains except (d) are texturally and chemically heterogeneous.

\subsection{Molecular-scale analysis of RDS and aquatic sediments}

The influence of oxidation state on the XANES spectra is revealed in differences in the shape and the position of the edge, as well as the presences of pre-edge and multiscattering resonances (MSR). As illustrated by the four model compounds in Fig. 3, a shift in the edge position of the $\mathrm{Cr} \mathrm{K}$ edge XANES to higher energies is generally discerned with increasing oxidation state. Such a shift may be used as a qualitative indicator of the presence of $\mathrm{Cr}(\mathrm{III}), \mathrm{Cr}(\mathrm{VI})$ or mixtures of different $\mathrm{Cr}$ oxidation states. Table 2 summarizes the energy values of pre-edge resonances, shoulder, absorption edge, edge crest and multi-resonance structures in XANES spectra at $\mathrm{Cr} \mathrm{K}$-edge for model compounds and environmental samples. 
Consideration of the environmental samples finds that the aquatic grain XANES spectra display similar profiles. The lack of an intense peak in the pre-edge region coupled with two small pre-edge resonances indicates that $\mathrm{Cr}$ in such samples is present mainly in the octahedrally coordinated trivalent form, and that the contribution of tetrahedrally coordinated $\mathrm{Cr}(\mathrm{VI})$ is estimated to be $\leq 5 \%$ (Huggins et al. 1999). Comparison of the pre-edge and edge position energies of the two aquatic samples spectra show comparability to the XANES spectra of the Cr(III) model compounds. In particular, the equivalence noted between the energies of the pre-edge resonance, edge crest and second MSR reported for Aquatic 1-51028 and those of $\mathrm{Cr}(\mathrm{OH})_{3}$ suggests that $\mathrm{Cr}(\mathrm{OH})_{3}$ is likely to be a main contributor to the $\mathrm{Cr}$ speciation of this sample. Differences in the energies of the pre-edge resonance and the second MSR reported for Aquatic 2-51029 may imply that $\mathrm{Cr}_{2} \mathrm{O}_{3}$ may also influence the $\mathrm{Cr}$ speciation of the Aquatic 2-51029.

Qualitative analysis of the XANES spectra of the RDS grains identifies a greater degree of variance between the individual spectra of the RDS. The edge position energies for the RDS grains, with the exception of RDS3-51050, appear to conform with values reported for the $\mathrm{Cr}$ (III) model compounds ( 6001.74 and $6002.43 \mathrm{eV}$ ) suggesting that $\mathrm{Cr}$ speciation is dominated by trivalent $\mathrm{Cr}$ species in the RDS samples. As with the aquatic samples, the presence of two low intensity pre-edge resonances identified in all the RDS samples, except RDS3-51050 and the absence of any sharp high intensity peak in the pre-edge region implies that $\mathrm{Cr}(\mathrm{VI})$ species play a secondary role to $\mathrm{Cr}(\mathrm{III})$ in the $\mathrm{Cr}$ speciation of RDS. Visual comparison of the five RDS spectra (Fig. 3) identifies strong similarities between RDS2-51044 and RDS5-51082 and to an extent, RDS151407. Consideration of the pre-edge resonance, edge and MSR energies determined for RDS2-51044 and RDS551082 finds agreement with those reported for $\mathrm{Cr}(\mathrm{OH})_{3}$ (Table 2). Although, RDS1-51407 spectra shows some comparability with that of $\mathrm{Cr}(\mathrm{OH})_{3}$, similarities to the edge position and MSR energies reported for $\mathrm{Cr}_{2} \mathrm{O}_{3}$ suggest that a combination of the two model compounds may be influential in this sample. The occurrence of shoulder structures in the XANES spectra of samples RDS3-51050 and RDS451059 infer that mixed oxidation states may exist in such samples (Berry and O'Neill 2004). The XANES spectrum of RDS3-51050 with the presence of a shoulder structure around $5990 \mathrm{eV}$ and edge crest and MSR energies of 6007 and $6022 \mathrm{eV}$, respectively, displays characteristics of $\mathrm{Cr}$ in metallic and trivalent forms. By contrast, XANES spectrum of RDS3-51059, is characterized by the prominence of an absorption edge shoulder, which is likely to result from a $1 \rightarrow 4 s$ transition indicative of $\mathrm{Cr}$ (III) being present and a MSR at approximately $6021 \mathrm{eV}$. 

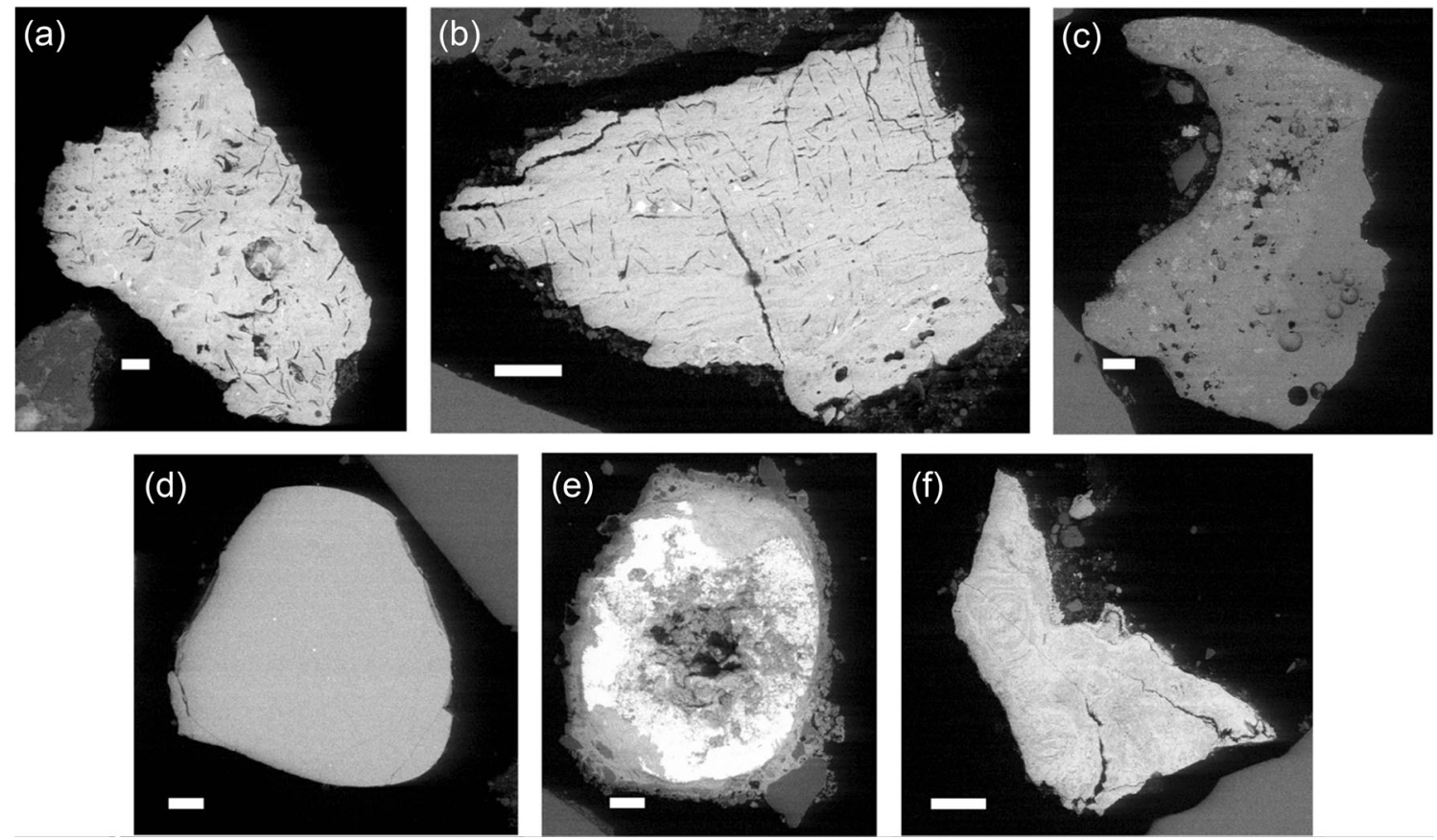

Fig. 2 Scanning electron microscope photomicrographs of Cr-bearing grains from RDS sample. Scale bar in each photomicrograph is $100 \mu \mathrm{m}$. a, b, e, and $\mathbf{f}$ Cr-bearing Fe oxides. c Mixed Cr-bearing Fe-Al silicate and Cr-bearing Fe-Mg-silicate. d Cr-bearing Fe silicate

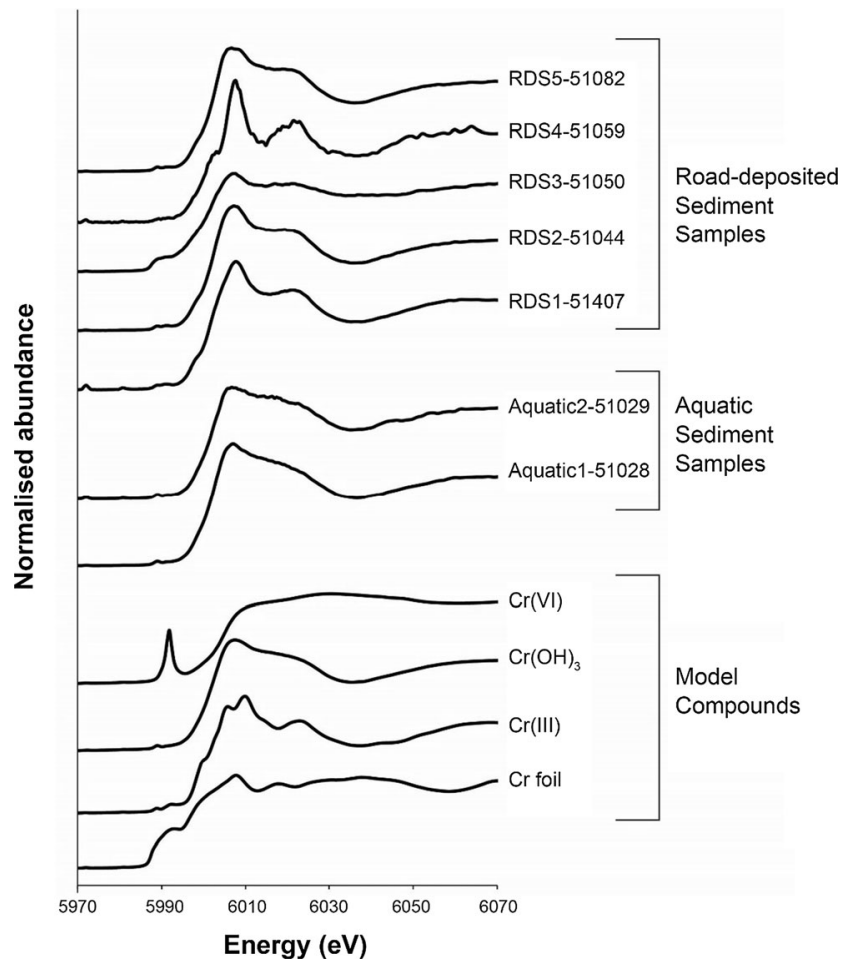

Fig. 3 Representative Cr K-edge XANES spectra for sediment particulates and $\mathrm{Cr}$ K-edge XANES spectra for model compounds. Note the dominance of $\mathrm{Cr}(\mathrm{III})$ and only small amounts of $\mathrm{Cr}(\mathrm{VI})$ in aquatic sediment particulates

\subsection{Geochemical analysis of alumino-silicate glass grains}

Pseudo-total metal concentration results for glass grains in the aquatic sediment are summarized in Table 3. All of the metals investigated have very high concentrations and can be classified as grossly contaminated when compared to Environment Agency (of England) guidelines for bulk sediments. Iron exhibits the highest mean metal concentration of $119,700 \mu \mathrm{g} \mathrm{g}^{-1}$. Chromium shows the lowest mean metal concentration of $260 \mu \mathrm{g} \mathrm{g}^{-1}$ which is similar to values reported for electron microprobe analysis. Sequential extraction analysis results for the glass grains are summarized in Table 3 and are represented as percentages associated with each geochemical phase in Fig. 4. Metals are primarily associated with the residual phase, although there is considerable variation between metals in the percentage found in chemically defined form. Over $60 \%$ of $\mathrm{Zn}$ is found in bioavailable forms, whereas less than $20 \%$ of $\mathrm{Cr}$ is found in these fractions. In terms of bioavailable fractions, all of the metals are primarily associated with the reducible fraction. The next most common association for metals is the oxidisable fraction. Lead and $\mathrm{Cr}$ show only weak associations with the exchangeable phase. Zinc exhibits the greatest percentage in the exchangeable phase and is the most widely distributed metal between phases - exchangeable (12\%), reducible (29\%), oxidisable (24\%), and residual (35\%). In comparison, $\mathrm{Cr}$ shows the least distribution between phases - exchangeable $(1 \%)$, reducible (7\%), oxidisable $(7 \%)$, and residual $(85 \%)$. 
Table 2 Energy values of pre-edge resonances, shoulder, absorption edge, edge crest and multi-resonance structures in XANES spectra at chromium $K$-edge for model compounds and environmental samples (values reported on eV)

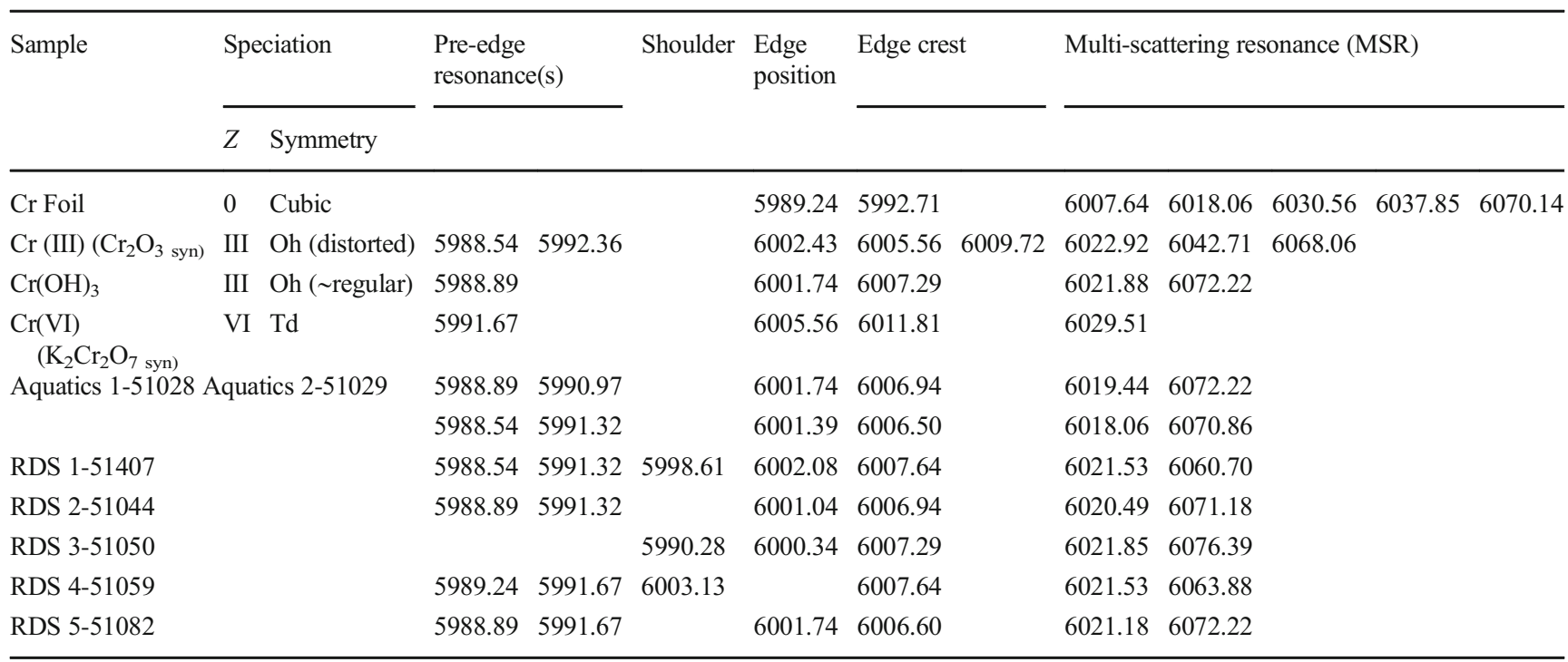

\section{Discussion}

\subsection{Speciation of chromium}

Chromium is present in high concentrations in urban particulate matter in Manchester and generally well above what is considered safe by soil and sediment quality guidelines. XANES analysis of $\mathrm{Cr}$ speciation suggests the dominance of relatively stable and non-toxic $\mathrm{Cr}(\mathrm{III})$ in both of the major grain types under study, with some trace amounts of $\mathrm{Cr}(\mathrm{VI})$ also detected. One of the key sources of $\mathrm{Cr}$-rich grains in the Salford Quays sediment is historically deposited slag. The findings of the present study that $\mathrm{Cr}$ exists in such material in the $\mathrm{Cr}(\mathrm{III})$ form, concurs with research carried out (Chaurand et al. 2006, 2007) on the Cr speciation of basic oxygen furnace steel slag, using XANES spectroscopy; $\mathrm{Cr}$ in BOF material was found to be present mainly in the octahedrally coordinated trivalent form. The dominance of $\mathrm{Cr}$ (III) species in RDS samples, may reflect the usage of by-products from industrial processes, in which Cr predominantly as exists in the trivalent form, in road construction (Chaurand et al. 2006). Experimental XANES spectra for the present study show strong similarities with those reported by Huggins et al. (2000) and Werner et al. (2007) for chromite and CrFe spinel, respectively, in ambient air particulate matter (AAPM). Potential sources of $\mathrm{Cr}-\mathrm{Fe}$ spinel to RDS include combustion by-products of $\mathrm{Cr}-\mathrm{Fe}$ containing fuel, road aggregate, as well as a soil component (Werner et al. 2007). Given the significant contribution $\mathrm{Cr}^{0}, \mathrm{Cr}_{2} \mathrm{O}_{3}$, and $\mathrm{Cr}(\mathrm{OH})_{3}$ to the $\mathrm{Cr}$ speciation in urban $\mathrm{PM}_{2.5}$ (Huggins et al. 2000; Werner et al. 2007), this suggests that RDS may be a potential and key source of $\mathrm{Cr}$ in AAPM. The dominance of $\mathrm{Cr}(\mathrm{III})$ in both the Manchester RDS and aquatic sediment suggests there might be limited biogeochemical weathering and opportunity for speciation change as the grains are transferred through the urban sediment cascade. However, it is impossible to confirm this hypothesis without undertaking similar analyses on sediment collected from pathways linking RDS and aquatic sinks.

Table 3 Mean concentrations $\left(\mu \mathrm{g} \mathrm{g}^{-1}\right)$ of metals in industrial glass particles from Salford Quays sediment $(n=3)$. Results are shown for pseudo-total metals and each geochemical phase of the sequential extraction

\begin{tabular}{|c|c|c|c|c|c|c|c|}
\hline & $\mathrm{Pb}$ & $\mathrm{Zn}$ & $\mathrm{Cu}$ & $\mathrm{Ni}$ & $\mathrm{Cr}$ & $\mathrm{Fe}$ & $\mathrm{Mn}$ \\
\hline Acid-soluble & $71 \pm 18$ & $1570 \pm 60$ & $512 \pm 21$ & $86 \pm 5$ & $2.68 \pm 0.08$ & $10,500 \pm 340$ & $275 \pm 14$ \\
\hline Reducible & $807 \pm 109$ & $4000 \pm 80$ & $1500 \pm 59$ & $284 \pm 9$ & $18.1 \pm 0.51$ & $27,700 \pm 260$ & $675 \pm 13$ \\
\hline Oxidisable & $130 \pm 41$ & $3290 \pm 116$ & $1130 \pm 43$ & $241 \pm 8$ & $17.57 \pm 1.72$ & $20,800 \pm 530$ & $459 \pm 17$ \\
\hline Residual & $1100 \pm 77$ & $4870 \pm 103$ & $3800 \pm 112$ & $285 \pm 51$ & $221 \pm 15$ & $60,800 \pm 1200$ & $609 \pm 67$ \\
\hline Pseudo-total & $2110 \pm 183$ & $13,700 \pm 214$ & $6950 \pm 109$ & $897 \pm 64$ & $259 \pm 13$ & $120,000 \pm 1300$ & $2020 \pm 99$ \\
\hline EA TEL guidelines* & 35 & 123 & 36.5 & 18 & 137.3 & - & - \\
\hline
\end{tabular}

* Environment Agency of England and Wales draft Threshold Effect Level (TEL) guidelines $\left(\mu \mathrm{g} \mathrm{g}^{-1}\right)$ for total metals in freshwater sediments (Environment Agency 2008) 


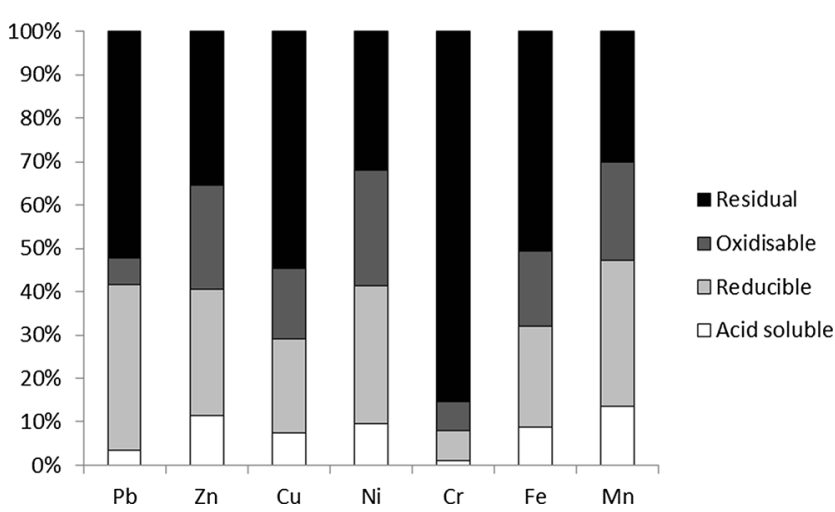

Fig. 4 Mean sequential extraction and residual $\mathrm{Pb}, \mathrm{Zn}, \mathrm{Cu}, \mathrm{Ni}, \mathrm{Cr}$, $\mathrm{Fe}$ and Mn concentrations $(n=3)$ from glass grains. Results are shown as percentages associated with each phase

Electron microbeam analysis of the particulate matter has found $\mathrm{Cr}$ to exist predominantly in Fe-rich and $\mathrm{Fe}$-poor glass grains in aquatic sediment and in both Fe oxides and Fe-rich glass grains in RDS. This supports earlier work on Manchester sediment (Taylor and Boult 2007; Taylor and Robertson 2009) and urban sediment worldwide (Kida and Sakai 2001; Lind et al. 2001; Reich 2003; Saffarzadeh et al. 2009) that suggests Fe oxides, derived from vehicular wear and tear, and Fe-rich glass grains, derived from metal smelting and concrete, are major hosts for contaminant metals in urban particulates. Iron oxides and $\mathrm{Fe}(\mathrm{III})$ oxyhydroxides are known to be important $\mathrm{Cr}$ scavengers and $\mathrm{Cr}$ (III) can readily substitute for Fe(III) in metal oxides (Frommer et al. 2009). Cr(III) can also coprecipitate with goethite $(\mathrm{FeOOH})$ to form an $(\mathrm{Fe}, \mathrm{Cr}) \mathrm{OOH}$ phase, due to structural similarities between the host $\mathrm{Fe}(\mathrm{III})$ mineral and the pure $\mathrm{Cr}$ surface precipitate phase $(\mathrm{CrOOH})$ (Charlet and Manceau 1992; Hansel et al. 2003). Cr(III) has also been found to dominate in hematite $\left(\mathrm{Fe}_{2} \mathrm{O}_{3}\right)$-bearing red mud from the Ajka (Hungary) tailings dam spill (Burke et al. 2012).

\subsection{Control of Eh and pH on the long-term environmental mobility of chromium}

Oxyanion-forming elements such as $\mathrm{Cr}$ have strong $\mathrm{pH}$ - and redox-dependent sorption behaviour. In anoxic conditions (e.g. in Salford Quays sediment), Cr(III) may be relatively stable as $\mathrm{Cr}(\mathrm{OH})_{3}$ or adsorbed to Fe oxides and glass grains. Phosphorus has been reported to scavenge trace metals $(\mathrm{Zn}$, $\mathrm{Cu}, \mathrm{Pb}$ ) in the Salford Quays by incorporating them into the mineral precipitate vivianite $\left(\mathrm{Fe}^{3+}\left(\mathrm{PO}_{4}\right)_{2} \cdot 8 \mathrm{H}_{2} 0\right)$ (Taylor and Boult 2007), although $\mathrm{Cr}$ was not considered in this previous study. Minor sulphate reduction has also been found in the Salford Quays which has been shown to be immobilizing $\mathrm{Cu}$ as an insoluble sulphide (Taylor and Boult 2007). However, $\mathrm{Cr}$ is not a divalent metal and will therefore not form an insoluble metal sulphide under reducing conditions. Chromium(III) solubility in anoxic sediments is further limited by complexation with solid-phase organic ligands which also facilitate the rapid reduction of $\mathrm{Cr}(\mathrm{VI})$ to $\mathrm{Cr}(\mathrm{III})$ (James 2002). The Salford Quays sediment is known to be rich in organic matter (up to $10 \%$ TOC in the upper, metalrich layers) (Taylor and Boult 2007).

Several studies have noted the oxidation of $\mathrm{Cr}$ (III) to $\mathrm{Cr}(\mathrm{VI})$ by $\mathrm{Mn}$ oxides in anoxic conditions Fendorf and Zasoski 1992; Apte et al. 2006; Tang et al. 2014; Kazakis et al. 2015). This natural oxidation is primarily related to the presence of Mn(III,IV) hydroxides which are considered as direct oxidising agents. Extensive experiments on the oxidation capacity of $\mathrm{Cr}$ (III) have shown that the $\mathrm{Mn}(\mathrm{IV})$ phase oxidizes the highest amount of $\mathrm{Cr}$ (III) (Landrot et al. 2012). Manceau and Charlet (1992) and Landrot et al. (2012), observed that $\mathrm{Cr}$ (III) was tightly sorbed as an inner-sphere complex to $\mathrm{Mn}(\mathrm{IV})$ in $\mathrm{Cr}(\mathrm{III})$-reacted $\mathrm{MnO}_{2}$ analysed by EXAFS. Manganese hydroxides were not found to be a major constituent of the urban particulate matter in the Salford Quays sediment (mean $0.75 \% \mathrm{MnO}$ in Fe-rich glasses; mean $0.37 \%$ $\mathrm{MnO}$ in RDS). However, these relatively low quantities of $\mathrm{Mn}$ can still make a significant difference to sorption behaviour (Jenne 1968) and the oxidation of $\mathrm{Cr}$ (III) to $\mathrm{Cr}$ (VI) by $\mathrm{Mn}$ oxides cannot be ruled out in urban aquatic sediment sinks.

Oxic conditions are not usual in sedimentary basins such as the Salford Quays due to limited water column mixing and high organic matter loading that maintains a high sediment oxygen demand. However, oxidation of canal, reservoir and harbour sediments can occur in response to dredging, flooding and bioturbation, leading to the phase transfer of some metals to more bioavailable species (Calmano et al. 1993; Zoumis et al. 2001). In the Salford Quays, Helixor pumps have been employed to oxygenate water in an effort to improve water quality and promote immobilization of cationic metals as hydroxides. Chromium(III) is still thermodynamically favourable even under mildly oxidizing conditions (Martello et al. 2007), but it is possible that the introduction of oxygen into the water column may promote oxidation of surface sediments leading to the oxidation of $\mathrm{Cr}(\mathrm{III})$ to $\mathrm{Cr}(\mathrm{VI})$. This could only occur, however, at Eh greater than 0.7 V (Takeno 2005). Enhanced $\mathrm{Cr}(\mathrm{VI})$ production has been reported previously in surface sediments of seasonally anoxic lakes (Achterberg and van den Berg 1997). However, in field experiments, Bloomfield and Pruden (1980) found both oxic and anoxic soil conditions increased the reduction of $\mathrm{Cr}(\mathrm{VI})$. Importantly, these experiments considered a typical soil $\mathrm{pH}$ of between 4 and 7, with $\mathrm{Cr}(\mathrm{VI})$ reduction being most efficient at $\mathrm{pH}<5$. While $\mathrm{Eh}$ is an important control on $\mathrm{Cr}$ speciation and mobility in sediment systems, $\mathrm{Cr}(\mathrm{VI})$ can only exist in both an oxic and high $\mathrm{pH}$ environment.

The most favourable environment for the formation of $\mathrm{Cr}(\mathrm{VI})$ species is Eh $>0.5 \mathrm{~V}$ and $\mathrm{pH}>8$ (Takeno 2005). The typical $\mathrm{pH}$ range for Salford Quays sediment is 6.6-7.6, and although Eh has not been measured, predominant anoxic 
conditions are inferred from the pore water chemistry (Taylor and Boult 2007). Therefore, future large-scale oxidation of $\mathrm{Cr}(\mathrm{III})$ to $\mathrm{Cr}(\mathrm{VI})$ is unlikely to occur in the Salford Quays sediment. However, this may not be the case in other $\mathrm{Cr}$ contaminated urban water bodies and careful investigation of the environmental processes that might drive $\mathrm{Cr}$ transformation is needed in order to comprehensively evaluate environmental risk. The formation of soluble $\mathrm{Cr}$ (III) species due to the dissolution of $\mathrm{Cr}(\mathrm{III})$ minerals and adsorbed species is the most likely mechanism by which $\mathrm{Cr}$ may mobilise from the sediments. The solubility of chromium hydroxide $\left[\mathrm{Cr}(\mathrm{OH})_{3}\right]$ is low between pH 6 and 12 and under reducing and mildly oxic conditions (Takeno 2005). As long as anoxic conditions remain, Cr-bearing Fe oxides may also exist as insoluble sulphide minerals or, more likely, incorporated into the phosphate mineral vivianite. However, most $\mathrm{Cr}$ in the aquatic sediment was found to be associated with glass grains. Furnacederived glasses in contaminated soils and sediments are known to be prone to chemical dissolution at sub-neutral $\mathrm{pH}$ due to organic acid generation as part of early sediment diagenesis Parsons et al. 2001; Lottermoser 2002). Taylor and Boult (2007) found evidence from petrographic observations of chemical dissolution occurring in Fe-rich glass grains and associated contaminant metal ( $\mathrm{Zn})$ release. However, $\mathrm{Cr}$ concentrations in pore waters were not measured so it remains unknown as to whether chemical dissolution may affect the cycling of $\mathrm{Cr}$ in urban aquatic sediment sinks. Evidence from the chemical extractions performed in the present study suggests $\mathrm{Cr}(\mathrm{III})$ has limited mobility and is not easily leached compared to other trace and toxic metals. However, the timeframe of exposure to low $\mathrm{pH}$ may be an important factor. Aqueous $\mathrm{Cr}$ species (e.g. $\mathrm{Cr}^{2+}, \mathrm{Cr}^{3+}$ ) can generally only exist at $\mathrm{pH}$ below 4 and while such low $\mathrm{pH}$ levels can occur in acidic soils, they are rarely encountered in sediments. Therefore, the release of organic acids during early diagenetic organic matter oxidation may not impact upon glass solubility and $\mathrm{Cr}$ mobility. However, it must be acknowledged that the presence of glass slag phases as major hosts of $\mathrm{Cr}$ is not reflected in grain-specific sequential chemical extraction methodologies (including BCR).

\section{Conclusions}

This study has provided important speciation and geochemical information that may have consequences for the long-term cycling of $\mathrm{Cr}$ in urban environments. Chromium has been found to exist primarily in two major grain types in urban particulate matter from the major urban conurbation of Manchester, UK. Chromium is mainly associated with Fe oxides and industrial glass grains in urban aquatic sediment. XANES analysis suggests this $\mathrm{Cr}$ exists primarily as the relatively non-toxic $\mathrm{Cr}$ (III) species. The predominant anoxic and neutral $\mathrm{pH}$ of the Salford Quays sediments suggests that this $\mathrm{Cr}$ (III) may be stable as long as these environmental conditions are maintained. While oxidation of the sediments may occur under a variety of scenarios, it is unlikely that sediment $\mathrm{pH}$ can be maintained at a high-enough level, in conjunction with oxic conditions, to mobilize $\mathrm{Cr}$ (III) as more soluble and toxic $\mathrm{Cr}(\mathrm{VI})$. Of course, this may not be the case in other urban aquatic sediment sinks that exhibit different environmental conditions to the Salford Quays. Aside from the issue of speciation, geochemical analyses have shown that most $\mathrm{Cr}$ is incorporated within the crystalline structure of industrial glass grains in the aquatic sediment and therefore exhibits limited environmental mobility in comparison to other trace metals. These glass grains may be prone to chemical dissolution at low $\mathrm{pH}$; however, it is unlikely that sediment $\mathrm{pH}$ can reach a low-enough level to mobilize aqueous $\mathrm{Cr}$ species. Industrial glass grains are a major component of urban sediment worldwide suggesting most $\mathrm{Cr}$ within the urban sediment cascade may be resistant to environmental processes that could mobilize more bioavailable forms. Future research should, through experiments and geochemical modelling, address this potential mobility under a variety of environmental scenarios. These data would facilitate the development of environmental risk models for $\mathrm{Cr}$ mobility and cycling in urban environments.

Acknowledgments We thank Andy Beard for assistance with electron microprobe analysis, Tina Geraki for help with XANES data acquisition at Diamond and James Rothwell for help with ICP-MS analysis of digested glass grains. We thank Diamond Light Source for access to beamline I18 (proposal SP3312) that contributed to the results presented here.

Open Access This article is distributed under the terms of the Creative Commons Attribution 4.0 International License (http:// creativecommons.org/licenses/by/4.0/), which permits unrestricted use, distribution, and reproduction in any medium, provided you give appropriate credit to the original author(s) and the source, provide a link to the Creative Commons license, and indicate if changes were made.

\section{References}

Achterberg EP, van den Berg CMG (1997) Chemical speciation of chromium and nickel in the western Mediterranean Deep-Sea. Res Pt Ii 44:693-720

Anderson RA (1989) Essentiality of chromium in humans. Sci Total Environ 86:75-81

Apte AD, Tare V, Bose P (2006) Extent of oxidation of Cr(III) to Cr(VI) under various conditions pertaining to natural environment. $\mathrm{J}$ Hazard Mater 128:164-174

Barrett JES, Taylor KG, Hudson-Edwards KA, Charnock JM (2010) Solid-phase speciation of $\mathrm{Pb}$ in urban road dust sediment: a XANES and EXAFS study. Environ Sci Technol 44:2940-2946

Barrett JES, Taylor KG, Hudson-Edwards KA, Charnock JM (2011) Solid-phase speciation of $\mathrm{Zn}$ in road dust sediment. Mineral Mag 75:2611-2629

Berry AJ, O'Neill HSC (2004) A XANES determination of the oxidation state of chromium in silicate glasses. Am Mineral 89:790-798 
Bloomfield C, Pruden G (1980) The behaviour of $\mathrm{Cr}(\mathrm{VI})$ in soil under aerobic and anaerobic conditions. Environ Pollut Series A, Ecol Biol 23:103-114

Broadway A, Cave MR, Wragg J, Fordyce FM, Bewley RJF, Graham MC, Byrne TN, Farmer JG (2010) Determination of the bioaccessibility of chromium in Glasgow soil and the implications for human health risk assessment. Sci Total Environ 409:267-277

Burke IT, Mayes WM, Peacock CL, Brown AP, Jarvis AP, Gruiz K (2012) Speciation of arsenic, chromium, and vanadium in red mud samples from the Ajka spill site, Hungary. Environ Sci Technol 46: 3085-3092

Butler BA (2009) Effect of pH, ionic strength, dissolved organic carbon, time, and particle size on metals release from mine drainage impacted streambed sediments. Water Res 43:1392-1402

Calmano W, Hong J, Forstner U (1993) Binding and mobilisation of heavy metals in contaminated sediments affected by $\mathrm{pH}$ and redox potential. Water Sci Technol 28:223-235

Charlet L, Manceau A (1992) Insitu characterization of heavy-metal surface-reactions - the chromium case. Int J Environ an Ch 46:97-108

Chaurand P, Rose J, Briois V, Olivi L, Hazemann J-L, Proux O, Domas J, Bottero J-Y (2007) Environmental impacts of steel slag reused in road construction: a crystallographic and molecular (XANES) approach. J Hazard Mater 139:537-542

Chaurand P, Rose J, Domas J, Bottero JY (2006) Speciation of Cr and V within BOF steel slag reused in road constructions. J Geochem Explor 88:10-14

Chen LX, Zhang XY, Lockard JV, Stickrath AB, Attenkofer K, Jennings G, Liu DJ (2010) Excited-state molecular structures captured by Xray transient absorption spectroscopy: a decade and beyond. Acta Crystallogr A 66:240-251

Farges F (2009) Chromium speciation in oxide-type compounds: application to minerals, gems, aqueous solutions and silicate glasses. Phys Chem Miner 36:463-481

Fendorf SE, Zasoski RJ (1992) Chromium(iii) oxidation by Delta-Mno2 .1. Characterization. Environ Sci Technol 26:79-85

Frommer J, Nachtegaal M, Czekaj I, Weng TC, Kretzschmar R (2009) Xray absorption and emission spectroscopy of Cr-III (Hydr)oxides: analysis of the K-pre-edge region. J Phys Chem A 113:1217112178

Hansel CM, Wielinga BW, Fendorf SR (2003) Structural and compositional evolution of $\mathrm{Cr} / \mathrm{Fe}$ solids after indirect chromate reduction by dissimilatory iron-reducing bacteria. Geochim Cosmochim Acta 67: 401-412

Huggins FE, Najih M, Huffman GP (1999) Direct speciation of chromium in coal combustion by-products by $\mathrm{x}$-ray absorption finestructure spectroscopy. Fuel 78:233-242

Huggins FE, Shah N, Huffman GP, Kolker A, Crowley S, Palmer CA, Finkelman RB (2000) Mode of occurrence of chromium in four US coals. Fuel Process Technol 63:79-92

James BR (2002) Chemical transformation of chromium in soils relevance to mobility, bio-availability and remediation The Chromium File 8

Jenne EA (1968) Controls on $\mathrm{Mn}, \mathrm{Fe}, \mathrm{Co}, \mathrm{Ni}, \mathrm{Cu}$, and $\mathrm{Zn}$ concentrations in soils and water: the significant role of hydrous $\mathrm{Mn}$ and $\mathrm{Fe}$ oxides. In: Baker RA (ed) Trace Inorganics in Water. Advances in Chemistry Series. American Chemical Society, Washington, pp 337-387

Kazakis N, Kantiranis N, Voudouris KS, Mitrakas M, Kaprara E, Pavlou A (2015) Geogenic Cr oxidation on the surface of mafic minerals and the hydrogeological conditions influencing hexavalent chromium concentrations in groundwater. Sci Total Environ 514:224-238

Kida A, Sakai S (2001) Metallic-phase lead in slag of municipal solid waste incineration ash and leaching characteristics. Waste Manag 3: 66-72

Knott NA, Aulbury JP, Brown TH, Johnston EL (2009) Contemporary ecological threats from historical pollution sources: impacts of large- scale resuspension of contaminated sediments on sessile invertebrate recruitment. J Appl Ecol 46:770-781

Kotas J, Stasicka Z (2000) Chromium occurrence in the environment and methods of its speciation. Environ Pollut 107:263-283

Landrot G, Tappero R, Webb SM, Sparks DL (2012) Arsenic and chromium speciation in an urban contaminated soil. Chemosphere 88: 1196-1201

Lind BB, Fallman AM, Larsson LB (2001) Environmental impact of ferrochrome slag in road construction. Waste Manag 21:255-264

Lottermoser B (2002) Exposure assessment of naturally metal enriched topsoils, Port Macquarie, Australia. Environ Geochem Health 24: 183-190

Manceau A, Charlet L (1992) X-ray absorption spectroscopic study of the sorption of $\mathrm{Cr}$ (iii) at the oxide water Interface .1. Molecular mechanism of Cr(iii) oxidation on Mn oxides. J Colloid Interf Sci 148: 425-442

Manceau A, Marcus MA, Tamura N (2002) Quantitative speciation of heavy metals in soils and sediments by synchrotron x-ray techniques. Rev Mineral Geochem 49:341-428

Martello L, Fuchsman P, Sorensen M, Magar V, Wenning RJ (2007) Chromium geochemistry and bioaccumulation in sediments from the lower Hackensack River, New Jersey. Arc environ Contam. Toxicol 53:337-350

Nriagu JO, Nieboer E (eds) (1988) Chromium in the natural and human environments. John Wiley, New York

Ohgami N, Yamanoshita O, Dinh Thang N, Nakano C, Wenting W, Ohnuma S, Kato M (2015) Carcinogenic risk of chromium, copper and arsenic in CCA-treated wood. Environ Pollut 206:456-460

Owens PN, Walling DE, Leeks GJL (1999) Use of floodplain sediment cores to investigate recent historical changes in overbank sedimentation rates and sediment sources in the catchment of the river Ouse, Yorkshire, UK. Catena 36:21-47

Pantelouris A, Modrow H, Pantelouris M, Hormes J, Reinen D (2004) The influence of coordination geometry and valency on the K-edge absorption near edge spectra of selected chromium compounds. Chem Phys 300:13-22

Parsons MB, Bird DK, Einaudi MT, Alpers CN (2001) Geochemical and mineralogical controls on trace element release from the Penn mine base-metal slag dump, California. Appl Geochem 16:1567-1593

Quevauviller P, Rauret G, LopezSanchez JF, Rubio R, Ure A, Muntau H (1997) Certification of trace metal extractable contents in a sediment reference material (CRM 601) following a three-step sequential extraction procedure. Sci Total Environ 205:223-234

Rauret G, López-Sánchez JF, Sahuquillo A, Rubio R, Davidson C, Ure A, $\mathrm{Ph}$. Quevauviller, Improvement of the BCR three step sequential extraction procedure prior to the certification of new sediment and soil reference materials. J Environ Monit 1(1):57-61

Ravel B, Newville M (2005) ATHENA, ARTEMIS, HEPHAESTUS: data analysis for $\mathrm{x}$-ray absorption spectroscopy using IFEFFIT. J Synchrotron Radiat 12:537-541

Reich J (2003) Slag from hazardous waste incineration: reduction of heavy metal leaching. Waste Manage Res 21:110-118

Robertson DJ, Taylor KG, Hoon SR (2003) Geochemical and mineral magnetic characterisation of urban sediment particulates, Manchester, UK. Appl Geochem 18:269-282

Saffarzadeh A, Shimaoka T, Motomura Y, Watanabe K (2009) Characterization study of heavy metal-bearing phases in MSW slag. J Hazard Mater 164:829-834

Stern AH (2010) A quantitative assessment of the carcinogenicity of hexavalent chromium by the oral route and its relevance to human exposure. Environ Res 110:798-807

Swietlik R, Molik A, Molenda M, Trojanowska M, Siwiec J (2011) Chromium(III/VI) speciation in urban aerosol. Atmos Environ 45: 1364-1368 
Takeno N (2005) Atlas of Eh-pH diagrams. Intercomparison of thermodynamic databases, National Institute of Advanced Industrial Science and Technology

Tang YZ, Webb SM, Estes ER, Hansel CM (2014) Chromium(III) oxidation by biogenic manganese oxides with varying structural ripening. Environ Sci-Proc Imp 16:2127-2136

Taylor KG, Boult S (2007) The role of grain dissolution and diagenetic mineral precipitation in the cycling of metals and phosphorus: a study of a contaminated urban freshwater sediment. Appl Geochem 22:1344-1358

Taylor KG, Owens PN (2009) Sediments in urban river basins: a review of sediment-contaminant dynamics in an environmental system conditioned by human activities. J Soils Sediments 9:281-303

Taylor KG, Robertson DJ (2009) Electron microbeam analysis of urban road-deposited sediment, Manchester, UK: improved source discrimination and metal speciation assessment. Appl Geochem 24: 1261-1269

Tenderholt A, Hedman B, Hodgson KO (2007) PySpline: a modern, cross-platform program for the processing of raw averaged XAS edge and EXAFS data x-ray absorption fine structure-XAFS13 882:105-107
Valerio F, Brescianini C, Mazzucotelli A, Frache R (1988) Seasonalvariation of thallium, lead, and chromium concentrations in airborne particulate matter collected in an urban area. Sci Total Environ 71: 501-509

Wei M, Liao J, Liu N, Zhang D, Kang J, Yang Y, Yang Y, Jin J (2007) Interaction between uranium and humic acid (I): adsorption behaviors of U(VI) in soil humic acids. Nucl Sci Tech 18:287-293

Werner ML, Nico PS, Marcus MA, Anastasio C (2007) Use of microXANES to speciate chromium in airborne fine particles in the Sacramento Valley. Environ Sci Technol 41:4919-4924

Xia K, Mehadi A, Taylor RW, Bleam WF (1997) X-ray absorption and electron paramagnetic resonance studies of $\mathrm{Cu}$ (II) sorbed to silica: surface-induced precipitation at low surface coverages. J Colloid Interf Sci 185:252-257

Yu XZ, Gu JD, Xing LQ (2008) Differences in uptake and translocation of hexavalent and trivalent chromium by two species of willows. Ecotoxicology 17:747-755

Zoumis T, Schmidt A, Grigorova L, Calmano W (2001) Contaminants in sediments: remobilisation and demobilisation. Sci Total Environ 226:195-202 